\title{
Hubungan Senam Tai Chi dengan Tekanan Darah dan Frekuensi Denyut Nadi pada Usia 45 Tahun ke Atas di Kelurahan Duri Kosambi Tahun 2017
}

\author{
Stefanie $^{1}$, Flora Rumiati², William ${ }^{2}$ \\ ${ }^{1}$ Fakultas Kedokteran dan Ilmu Kesehatan Universitas Kristen Krida Wacana \\ ${ }^{2}$ Departemen Fisiologi Fakultas Kedokteran dan Ilmu Kesehatan \\ Universitas Kristen Krida Wacana \\ Alamat Korespondensi: florarum@yahoo.com
}

\begin{abstract}
Abstrak
Prevalensi hipertensi dan penyakit kardiovaskular lainnya meningkat sesuai dengan bertambahnya usia. Salah satu upaya meningkatkan kesehatan yang terutama diminati oleh kelompok usia menengah ke atas adalah Tai Chi. Tujuan penelitian ini adalah untuk mengetahui hubungan senam Tai Chi dengan tekanan darah dan frekuensi denyut nadi pada usia 45 tahun ke atas dengan maupun tanpa riwayat penyakit kardiovaskular. Penelitian ini merupakan penelitian analitik observasional dengan pendekatan cross sectional. Subjek penelitian sebanyak 60 orang berusia 45 tahun ke atas yang terdiri dari dua kelompok, kelompok yang mengikuti senam Tai Chi $(\mathrm{n}=30)$ dan kelompok yang tidak mengikuti senam Tai Chi $(\mathrm{n}=30)$ di Kelurahan Duri Kosambi. Variabel yang diukur yaitu tekanan darah sistolik, diastolik, dan frekuensi denyut nadi. Perbedaan bermakna atau hubungan antara senam Tai Chi pada kedua kelompok dianalisis dengan uji t tidak berpasangan dan uji Mann-Whitney. Hasil penelitian menunjukkan pada kelompok yang tidak memiliki riwayat penyakit kardiovaskular terdapat hubungan atau perbedaan bermakna $(\mathrm{p}<0,05)$ antara senam Tai Chi dengan tekanan darah sistolik $(\mathrm{p}=0,011)$, namun tidak terdapat hubungan $(\mathrm{p}>0,05)$ terhadap tekanan darah diastolik $(\mathrm{p}=0,362)$ dan frekuensi denyut nadi $(\mathrm{p}=0,525)$. Pada kelompok yang memiliki riwayat penyakit kardiovaskular baik konsumsi obat kardiovaskular dan tidak, didapatkan adanya hubungan antara senam Tai Chi dengan tekanan darah sistolik $(\mathrm{p}=0,009)$ dan frekuensi denyut nadi $(\mathrm{p}=0,002)$, namun tidak ditemukan adanya hubungan antara senam Tai Chi dengan tekanan darah diastolik $(\mathrm{p}=0,057)$. Dari penelitian ini disimpulkan bahwa terutama terdapat hubungan antara senam Tai Chi dengan tekanan darah sistolik pada kelompok dengan maupun tanpa riwayat penyakit kardiovaskular, dan frekuensi denyut nadi (pada kelompok dengan riwayat penyakit kardiovaskular), namun tidak dengan tekanan diastolik.
\end{abstract}

Kata kunci: frekuensi denyut nadi, senam Tai Chi, tekanan darah, usia 45 tahun ke atas

\section{Relationship between Tai Chi, Blood Pressure and Pulse Rate among 45 Years and abobe at Duri Kosambi Subdistrict in 2017}

\begin{abstract}
The prevalence of hypertension and other cardiovascular diseases increases with age. Tai Chi is a health promotion effort particularly popular among middle to late age groups. The purpose of this research is to determine the relationship between Tai Chi and blood pressure and heart rate among subjects age 45 years and above. This is an observational analytic cross sectional study. The subjects were 60 persons whose age are 45 years old and above from two groups, the group who participated in Tai Chi $(n=30)$ and the group that did not participate in Tai Chi exercises $(n=30)$ in Duri Kosambi. The variables measured were systolic and diastolic blood pressure as well as heart rate. Significant difference or the relationship between Tai Chi and both groups were measured using independent $t$-test and Mann-Whitney test. The results showed that in the group with no history of cardiovascular diseases, there is an association ( $p<0.05)$ or significant difference between Tai Chi and systolic blood pressure $(p=0.011)$, but there was no significant difference $(p>0,05)$ in diastolic blood pressure $(p=0,362)$ and
\end{abstract}


heart rate $(p=0.525)$. In the group with the history of cardiovascular diseases with or without consumption of cardiovascular medicines, Tai Chi was related to systolic blood pressure $(p=0.009)$ and heart rate ( $p=0.002)$, but no significant association was found between Tai Chi and diastolic blood pressure $(p=0,057)$. In conclusion, Tai Chi was related to both systolic blood pressure and heart rate, and on the contrary there is no association between Tai Chi and diastolic blood pressure. Keywords: heart rate, Tai Chi, blood pressure, 45 years of age and above

\section{Pendahuluan}

Banyak faktor yang dapat memerbesar risiko atau kecenderungan seseorang menderita hipertensi, seperti umur, jenis kelamin, faktor genetik, serta faktor lingkungan yang meliputi obesitas, stres, konsumsi garam, merokok, konsumsi alkohol, dan sebagainya. ${ }^{1}$ Menurut data World Health Organisation (WHO), di seluruh dunia, sekitar 972 juta orang atau 26,4\% penghuni bumi mengidap hipertensi, angka ini kemungkinan akan meningkat menjadi 29,2\% di tahun 2025. Dari 972 juta pengidap hipertensi, 333 juta berada di negara maju dan 639 sisanya berada di negara sedang berkembang, termasuk Indonesia. ${ }^{1}$ Proporsi penderita penyakit kardiovaskular yang dirawat di rumah sakit di Indonesia terus meningkat dari $2,1 \%$ di tahun 1990 menjadi 6,8\% di tahun $2001 .^{1}$

Salah satu indikator utama tingkat kesehatan masyarakat adalah meningkatnya usia harapan hidup. Dengan meningkatnya usia harapan hidup, berarti semakin banyak penduduk lanjut usia (lansia). ${ }^{2}$ Batasan umur menurut WHO, ada empat tahap lansia meliputi usia pertengahan (middle age) yaitu kelompok usia 45-59 tahun, lanjut usia (elderly) antara 6074 tahun, lanjut usia tua (old) antara 75-90 tahun, dan usia sangat tua (very old) di atas 90 tahun. ${ }^{3}$ Olahraga atau latihan fisik pada orang tua yang dilakukan secara rutin akan mengurangi risiko penumpukan lemak pada dinding pembuluh darah, yang akhirnya akan menjaga elastisitasnya dan melatih otot jantung dalam berkontraksi, sehingga kemampuan pemompaannya akan selalu terjaga. ${ }^{4}$

Senam Tai Chi banyak dilakukan di berbagai negara seperti Tiongkok dan bahkan seluruh Asia. Tai Chi merupakan olahraga intensitas ringan yang memiliki aktivitas aerobik. ${ }^{5}$ Tai Chi berasal dari seni bela diri kuno dan mengombinasikan aktivitas fisik yang lembut dengan elemen meditasi, perhatian terhadap tubuh dan pernapasan, serta pikiran. ${ }^{6}$ Berbagai literatur dan studi mendeskripsikan keuntungan dari senam Tai Chi, mulai dari keseimbangan tubuh dan reduksi kejadian jatuh pada dewasa yang lemah, memerbaiki kualitas hidup dan gejala rheumatoid arthritis, human immunodeficiency virus, kanker, dan gagal jantung. ${ }^{6}$

Orang yang tidak aktif cenderung memunyai frekuensi denyut jantung yang lebih tinggi. Sehingga otot jantungnya harus bekerja lebih keras pada setiap kontraksi. Semakin keras dan sering otot jantung memompa, maka semakin tinggi tekanan yang dibebankan pada arteri. $^{7}$ Oleh karena itu, peneliti ingin mengetahui apakah dengan melakukan senam Tai Chi secara rutin dapat memengaruhi tekanan darah dan frekuensi denyut nadi subjek penelitian.

\section{Tekanan Darah dan Denyut Nadi}

Tekanan darah adalah daya yang diperlukan agar darah dapat mengalir di dalam pembuluh darah dan beredar mencapai semua jaringan tubuh manusia. Darah dengan lancar beredar ke seluruh bagian tubuh, berfungsi sangat penting sebagai media pengangkut oksigen serta zat-zat lain yang diperlukan bagi kehidupan sel-sel tubuh, selain itu darah juga berfungsi sebagai pengangkut sisa hasil metabolisme yang tidak berguna lagi dari jaringan tubuh. ${ }^{8}$

Denyut nadi memiliki hubungan positif terhadap inflamasi subklinis dan peningkatan denyut nadi, dapat juga menjadi tanda subklinis dari penyakit jantung. Prognosis buruk yang terkait dengan denyut nadi yang tinggi kemungkinan sebagian diakibatkan oleh kedua efek tersebut. ${ }^{9} \quad$ Studi epidemiologi menunjukkan bahwa denyut nadi merupakan prediktor dari segala penyebab morbiditas dan mortalitas kardiovaskular, termasuk yang belum terdiagnosis penyakit kardiovaskular. Studi pada hewan menunjukkan denyut nadi cepat dapat memercepat terjadinya coronary atherosclerosis yang merupakan prediktor independen dari penyakit jantung koroner (PJK). ${ }^{9}$ Terapi penurunan denyut nadi pada studi hewan juga mengurangi progresi dari aterosklerosis. Denyut nadi yang tinggi juga meningkatkan risiko terjadinya trombosis 
koroner. Selain itu aktivasi simpatis mendukung terjadinya aritmia ventrikular yang mengancam nyawa. ${ }^{9}$

\section{Hipertensi dan Risiko Penyakit Kardiovaskular}

Hipertensi merupakan penyakit yang sering disebut sebagai silent killer, jika tidak terkontrol dapat memicu timbulnya penyakit degeneratif, seperti gagal jantung kongestif, gagal ginjal, dan berbagai penyakit vaskuler. ${ }^{3}$ Faktor-faktor yang memengaruhi terjadinya hipertensi dibagi dalam dua kelompok besar, yaitu faktor yang melekat atau tidak dapat diubah seperti jenis kelamin, umur, genetik, dan faktor yang dapat diubah seperti pola makan, kebiasaan olahraga, dan lain-lain. ${ }^{10}$

Hipertensi telah menjadi tantangan dan masalah yang serius bagi kesehatan masyarakat di dunia, tidak hanya karena tingginya prevalensi tetapi juga faktor risiko utama penyakit kardiovaskular dan penyakit ginjal. Prevalensi hipertensi meningkat seiring dengan bertambahnya umur, dan lebih dari $70 \%$ di antara laki-laki yang berumur 65 tahun menderita hipertensi. ${ }^{11}$ Menurut Joint National Committee (JNC) VII tahun 2003, tekanan darah normal yaitu tekanan sistolik $<120$ $\mathrm{mmHg}$ dan tekanan diastolik $<80 \mathrm{mmHg}$, prehipertensi yaitu tekanan sistolik 120-139 $\mathrm{mmHg}$ atau tekanan diastolik $80-89 \mathrm{mmHg}$, hipertensi derajat I yaitu tekanan sistolik 140$159 \mathrm{mmHg}$ atau tekanan diastolik 90-99 $\mathrm{mmHg}$, dan hipertensi derajat II yaitu tekanan sistolik $\geq 160 \mathrm{mmHg}$ atau tekanan diastolik $\geq 100$ mmHg. ${ }^{12}$

Di Indonesia masalah hipertensi cenderung meningkat. Hasil Survei Kesehatan Rumah Tangga (SKRT) tahun 2001 menunjukkan bahwa $8,3 \%$ penduduk menderita hipertensi dan meningkat menjadi $27,5 \%$ pada tahun 2004. ${ }^{13}$ Penelitian epidemiologi membuktikan bahwa hipertensi berhubungan secara linear dengan morbiditas dan mortalitas penyakit kardiovaskular. ${ }^{13}$ Dalam sebuah studi metaanalisis ditemukan bahwa penurunan rerata tekanan darah sistolik sebesar $2 \mathrm{mmHg}$ dapat menurunkan risiko mortalitas akibat penyakit jantung iskemik sebesar 7\%. ${ }^{14}$

Denyut jantung meningkat pada saat tubuh melakukan aktivitas lebih, dan pernafasan juga meningkat untuk memenuhi kebutuhan oksigen pada metabolisme tubuh. ${ }^{15}$ Denyut nadi distimulasi oleh serabut saraf simpatis dan penurunan frekuensi denyut nadi distimulasi oleh serabut parasimpatis. ${ }^{16}$ Pelatihan yang bersifat aerobik memberi perubahan pada fisiologis tubuh karena hal tersebut melatih jantung menerima beban latihan fisik, menyebabkan otot jantung bertambah kuat sehingga dapat memompa darah lebih kuat dan hal ini meningkatkan curah jantung, sehingga dapat menurunkan denyut nadi istirahat. ${ }^{17}$ Selain itu peningkatan intensitas pada kontraksi otot akan meningkatkan ukuran serat otot, meningkatkan mioglobin dalam serat otot, meningkatkan jumlah pembuluh darah kapiler yang melayani serat otot, sehingga hal tersebut menyebabkan meningkatnya kemampuan otot yang menandakan kebugaran fisik semakin tinggi. ${ }^{17}$

Obesitas secara umum khususnya obesitas abdominal berhubungan dengan risiko morbiditas dan mortalitas. Penyebab utama kematian berkaitan dengan obesitas adalah penyakit kardiovaskular, dengan obesitas abdominal sebagai salah satu faktor predisposisi. Pengukuran waist-hip ratio telah terbukti menggambarkan adipositas abdominal, dan dilakukan dalam memprediksi risiko penyakit kardiovaskular. ${ }^{18}$

\section{Metodologi Penelitian}

Penelitian ini adalah penelitian analitik observasional dengan pendekatan cross sectional. Pengambilan sampel dilakukan di Kelurahan Duri Kosambi, Jakarta Barat. Penelitian ini dilakukan pada bulan Oktober hingga Desember tahun 2017. Subjek penelitian dengan total jumlah 60 responden terbagi menjadi dua kelompok yaitu kelompok yang melakukan senam Tai Chi berjumlah 30 responden dan kelompok yang tidak melakukan Tai Chi berjumlah 30 responden. Pengambilan sampel pada penelitian ini menggunakan total sampling dan purposive sampling. Subjek yang melakukan senam Tai Chi harus memiliki kriteria inklusi antara lain pria dan wanita berusia 45 tahun ke atas, bertempat tinggal di Kelurahan Duri Kosambi, rutin mengikuti senam Tai Chi rutin minimal tiga kali dalam seminggu selama tiga bulan, bersedia menjadi subjek penelitian, sedangkan kriteria eksklusi melakukan aktivitas olahraga lain dan tidak bersedia menjadi subjek penelitian. Subjek yang tidak melakukan senam Tai Chi harus memiliki kriteria inklusi pria dan wanita berusia 45 tahun ke atas, bertempat tinggal di Kelurahan Duri Kosambi, tidak mengikuti senam Tai Chi atau aktivitas olahraga lain, 
bersedia menjadi subjek penelitian, sedangkan kriteria eksklusi melakukan senam Tai Chi atau aktivitas olahraga lain, dan tidak bersedia menjadi subjek penelitian.

Variabel bebas pada penelitian ini adalah senam $T a i$ Chi, sedangkan variabel terikat yang akan diukur adalah tekanan darah dan frekuensi denyut nadi. Pengukuran tekanan darah subjek menggunakan alat stetoskop dan sfigmomanometer air raksa pada bagian lengan kanan yang diletakkan di atas meja dengan posisi subjek duduk tegak dan keadaan relaks. Pengukuran tekanan darah dilakukan sebanyak dua kali dan diberi jeda waktu dua menit. Jika hasil pengukuran kedua berbeda $\geq 10 \mathrm{mmHg}$ dibanding pengukuran pertama, maka dilakukan pengukuran ketiga. Dua data pengukuran dengan selisih terkecil dengan pengukuran terakhir dihitung reratanya sebagai hasil ukur tensi. Bagi subjek yang mengikuti senam Tai Chi, pengukuran tekanan darah dilakukan 30 menit setelah senam, karena tekanan darah yang meningkat memerlukan waktu untuk kembali ke tekanan darah semula. Bagi subjek yang tidak mengikuti senam Tai Chi, dapat diukur tekanan darahnya dalam keadaan basal atau tidak melakukan aktivitas selama sepuluh menit sebelum pengukuran. Pengukuran dilakukan oleh pemeriksa yang sama.

Pada penelitian ini pengukuran frekuensi denyut nadi dilakukan dengan perabaan pada arteri radialis selama 30 detik menggunakan stopwatch dan hasilnya dikalikan dua sehingga didapatkan frekuensi denyut nadi per menit. Pengolahan statistik data menggunakan SPSS ver 16. Uji normalitas dilakukan untuk menentukan jenis uji bivariat yang tepat untuk mengolah variabel penelitian. Jika variabel penelitian memiliki distribusi normal $(p>0,05)$ maka dilakukan uji t tidak berpasangan (independent t-test), sebaliknya jika tidak memiliki distribusi normal $(\mathrm{p}<0,05)$ maka dilakukan uji Mann-Whitney.

\section{Kaji Etik}

Penelitian ini dinyatakan telah lolos kaji etik dengan nomor 370/SLKEIM/LIKKW/FK/KE/X/2017 dari Komite Etik Penelitian Medis dan Kesehatan Fakultas Kedokteran dan Ilmu Kesehatan Universitas Kristen Krida Wacana.

\section{Hasil Penelitian}

Penelitian menunjukkan terdapat variasi tekanan darah sistolik, diastolik, dan denyut nadi dari subjek penelitian. Faktorfaktor yang kemungkinan menjadi bias dalam hasil penelitian terkontrol melalui penyaringan subjek penelitian menggunakan kuesioner. Perbandingan hasil tekanan darah sistolik, diastolik, dan denyut nadi pada subjek yang memiliki riwayat penyakit kardiovaskular seperti hipertensi, hipotensi, penyakit jantung, stroke, dan kelainan darah, serta konsumsi obat-obatan penyakit kardiovaskular dikategorikan masing-masing untuk mencegah kerancuan hasil penelitian (Tabel 1).

Analisis bivariat dilakukan untuk mengetahui hubungan atau perbedaan bermakna antara tekanan darah sistolik, diastolik, dan denyut nadi dengan senam Tai Chi.

Berdasarkan Tabel 2, didapatkan bahwa terdapat hubungan atau perbedaan bermakna antara senam Tai Chi dengan tekanan darah sistolik, karena hasil analisis menunjukkan bahwa nilai $\mathrm{p}(0,011)<0,05$. Sebaliknya tidak ditemukan adanya hubungan atau perbedaan bermakna antara senam Tai Chi dengan tekanan darah diastolik dan frekuensi denyut nadi, karena hasil analisis menunjukkan bahwa tekanan diastolik memiliki nilai $\mathrm{p}$ $(0,362)>0,05$ dan frekuensi denyut nadi memiliki nilai $\mathrm{p}(0,525)>0,05$. Perbandingan ketiga variabel tersebut dapat dilihat pada Gambar 1 dan 2.

Berdasarkan Tabel 3, didapatkan bahwa terdapat hubungan atau perbedaan bermakna antara senam Tai Chi dengan tekanan darah sistolik dan frekuensi denyut nadi, karena hasil analisis menunjukkan bahwa tekanan sistolik memiliki nilai $\mathrm{p}(0,009)<0,05$, dan frekuensi denyut nadi memiliki nilai $\mathrm{p}(0,002)$ $<0,05$. Sebaliknya tidak ditemukan adanya hubungan atau perbedaan bermakna antara senam Tai Chi dengan tekanan darah diastolic, karena hasil analisis menunjukkan bahwa nilai $p(0,057)>0,05$. Perbandingan ketiga variabel tersebut dapat dilihat pada Gambar 3 dan 4.

Berdasarkan Tabel 4, didapatkan bahwa terdapat hubungan atau perbedaan bermakna antara senam Tai Chi dengan tekanan darah sistolik $(\mathrm{p}=0,009)$ dan frekuensi denyut nadi $(\mathrm{p}=0,002)$. Sebaliknya tidak ditemukan adanya hubungan atau perbedaan bermakna antara senam Tai Chi dengan tekanan darah diastolik $(\mathrm{p}=0,057)$. Perbandingan ketiga 
variabel tersebut dapat dilihat pada Gambar 5

dan 6.

Tabel 1. Distribusi Frekuensi Karakteristik Responden

\begin{tabular}{|c|c|c|c|c|}
\hline \multirow{2}{*}{$\begin{array}{c}\text { Karakteristik } \\
\text { Responden }\end{array}$} & \multicolumn{2}{|c|}{ Senam Tai Chi } & \multicolumn{2}{|c|}{ Tidak Senam Tai Chi } \\
\hline & Jumlah & Persentase $(\%)$ & Jumlah & Persentase $(\%)$ \\
\hline \multicolumn{5}{|l|}{ Jenis Kelamin } \\
\hline Pria & 7 & 23,3 & 11 & 36,7 \\
\hline Wanita & 23 & 76,7 & 19 & 63,3 \\
\hline \multicolumn{5}{|l|}{ Minum Obat } \\
\hline Tidak Minum Obat & 15 & 50 & 24 & 80 \\
\hline Minum Obat & 15 & 50 & 6 & 20 \\
\hline \multicolumn{5}{|l|}{ Riwayat Penyakit } \\
\hline Tidak Ada & 12 & 40 & 15 & 50 \\
\hline Ada & 18 & 60 & 15 & 50 \\
\hline \multicolumn{5}{|l|}{ Merokok } \\
\hline Tidak merokok & 29 & 96,7 & 28 & 93,3 \\
\hline Merokok & 1 & 3,3 & 2 & 6,7 \\
\hline \multicolumn{5}{|l|}{ Waist-Hip-Ratio } \\
\hline Tidak Berisiko & 0 & 0 & 0 & 0 \\
\hline Berisiko & 30 & 100 & 30 & 100 \\
\hline
\end{tabular}

Tabel 2. Hasil Rerata Pemeriksaan Tekanan Darah dan Frekuensi Denyut Nadi pada Subjek Tanpa Riwayat Penyakit Kardiovaskular

\begin{tabular}{cccc}
\hline Variabel Penelitian & Senam Tai Chi & Tidak Senam Tai Chi & p value \\
\hline Tekanan darah sistolik & $115,83 \pm 13,953$ & $129,33 \pm 11,629$ & $0,011^{*}$ \\
Tekanan darah diastolik & $79,13 \pm 9,731$ & $82,33 \pm 7,988$ & $0,362^{*}$ \\
Frekuensi denyut nadi & $78,33 \pm 5,314$ & $80,27 \pm 9,968$ & $0,525^{*}$ \\
\hline
\end{tabular}

* Uji t tidak berpasangan (bermakna jika $\mathrm{p}<0,05$ )

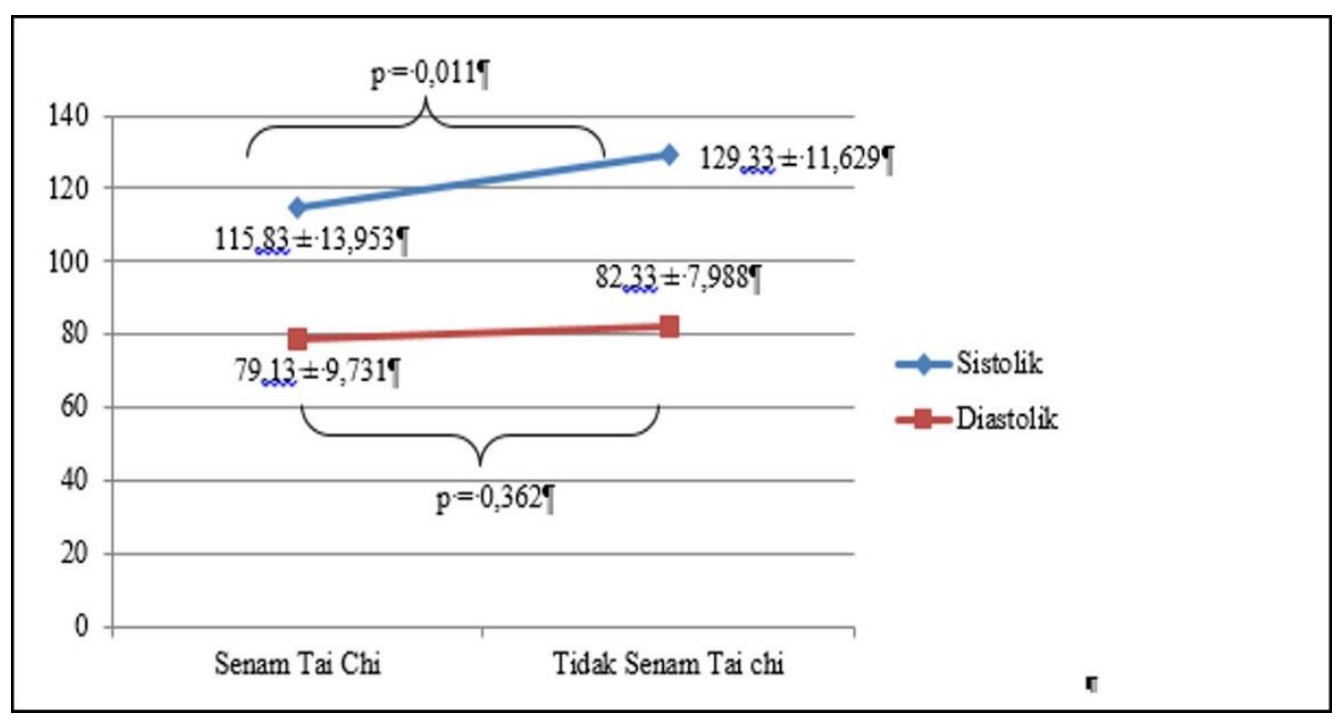

Gambar 1. Perbandingan Tekanan Darah pada Subjek Tanpa Riwayat Penyakit Kardiovaskular 


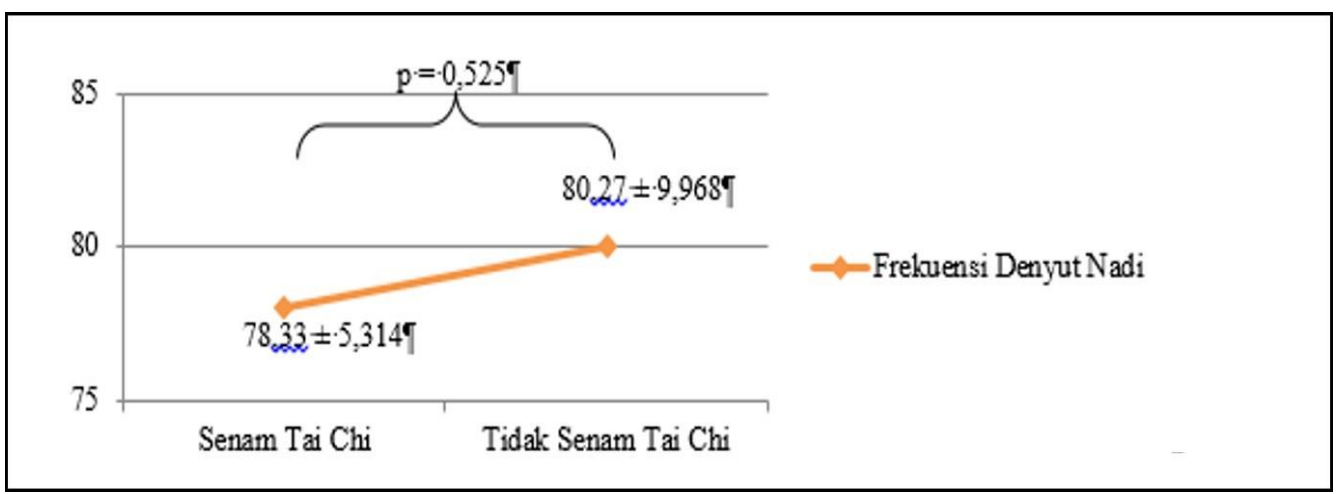

Gambar 2. Perbandingan Frekuensi Denyut Nadi pada Subjek Tanpa Riwayat Penyakit Kardiovaskular

Tabel 3. Hasil Rerata Pemeriksaan Tekanan Darah dan Frekuensi Denyut Nadi pada Subjek dengan Riwayat Penyakit Kardiovaskular Tanpa Konsumsi Obat Penyakit Kardiovaskular

\begin{tabular}{cccc}
\hline Variabel Penelitian & Senam Tai Chi & Tidak Senam Tai Chi & p value \\
\hline Tekanan darah sistolik & $103,33 \pm 5,774$ & $138,33 \pm 11,726$ & $0,009^{* *}$ \\
Tekanan darah diastolik & $76,67 \pm 5,274$ & $83,33 \pm 5,590$ & $0,057^{* *}$ \\
Frekuensi denyut nadi & $82,67 \pm 8,083$ & $87,89 \pm 8,069$ & $0,002^{*}$ \\
\hline * Uji t tidak berpasangan (bermakna jika $<<0,05)$ & & \\
** Uji Mann-Whitney (bermakna jika $\mathrm{p}<0,05)$ & &
\end{tabular}

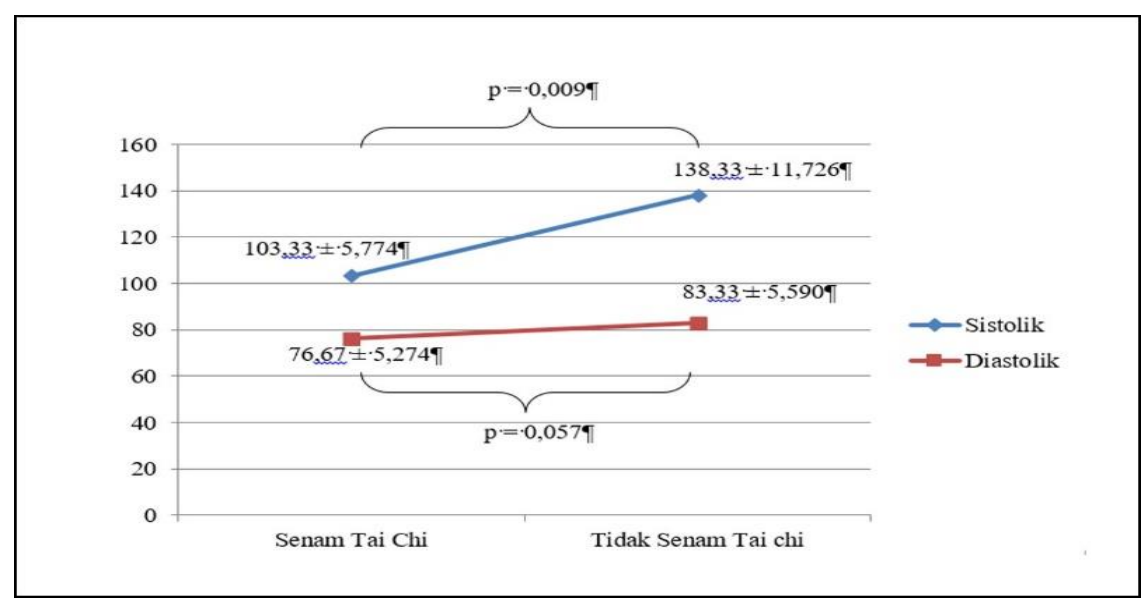

Gambar 3. Perbandingan Tekanan Darah pada Subjek dengan Riwayat Penyakit Kardiovaskular Tanpa Konsumsi Obat Penyakit Kardiovaskular

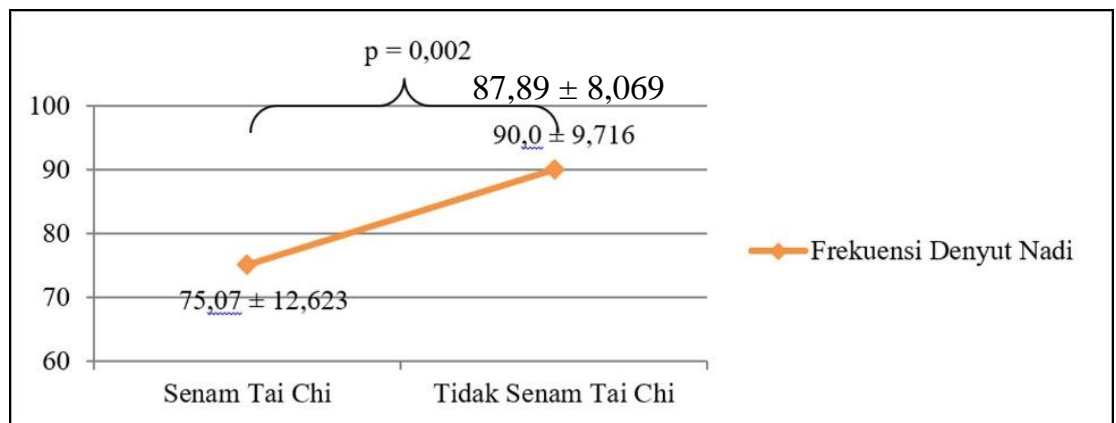

Gambar 4. Perbandingan Frekuensi Denyut Nadi pada Subjek dengan Riwayat Penyakit Kardiovaskular Tanpa Konsumsi Obat Penyakit Kardiovaskular 
Tabel 4. Hasil Rerata Pemeriksaan Tekanan Darah dan Frekuensi Denyut Nadi pada Subjek Dengan Riwayat Penyakit Kardiovaskular dan Konsumsi Obat Penyakit Kardiovaskular

\begin{tabular}{cccc}
\hline Variabel Penelitian & Senam Tai Chi & Tidak Senam Tai Chi & p value \\
\hline & & & \\
Tekanan darah sistolik & $128,67 \pm 16,198$ & $143,33 \pm 5,164$ & $0,009 * *$ \\
Tekanan darah diastolik & $80 \pm 8,018$ & $86,67 \pm 12,111$ & $0,057 * *$ \\
Frekuensi denyut nadi & $75,07 \pm 12,623$ & $90,0 \pm 9,716$ & $0,002^{*}$ \\
& & & \\
\hline * Uji t tidak berpasangan (bermakna jika $<<0,05)$ & & \\
** Uji Mann-Whitney (bermakna jika $p<0,05)$ &
\end{tabular}

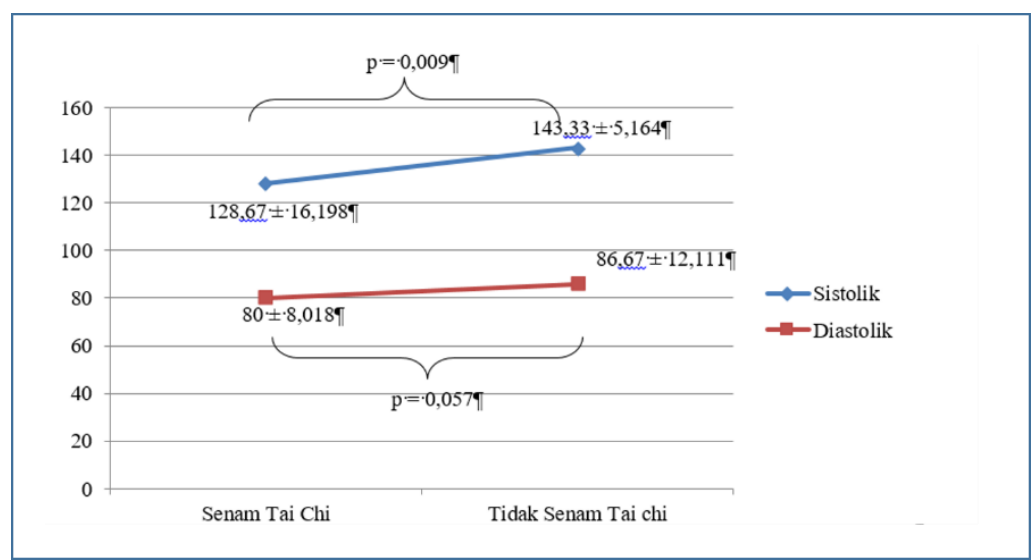

Gambar 5. Perbandingan Tekanan Darah pada Subjek dengan Riwayat Penyakit Kardiovaskular dan Konsumsi Obat Penyakit Kardiovaskular

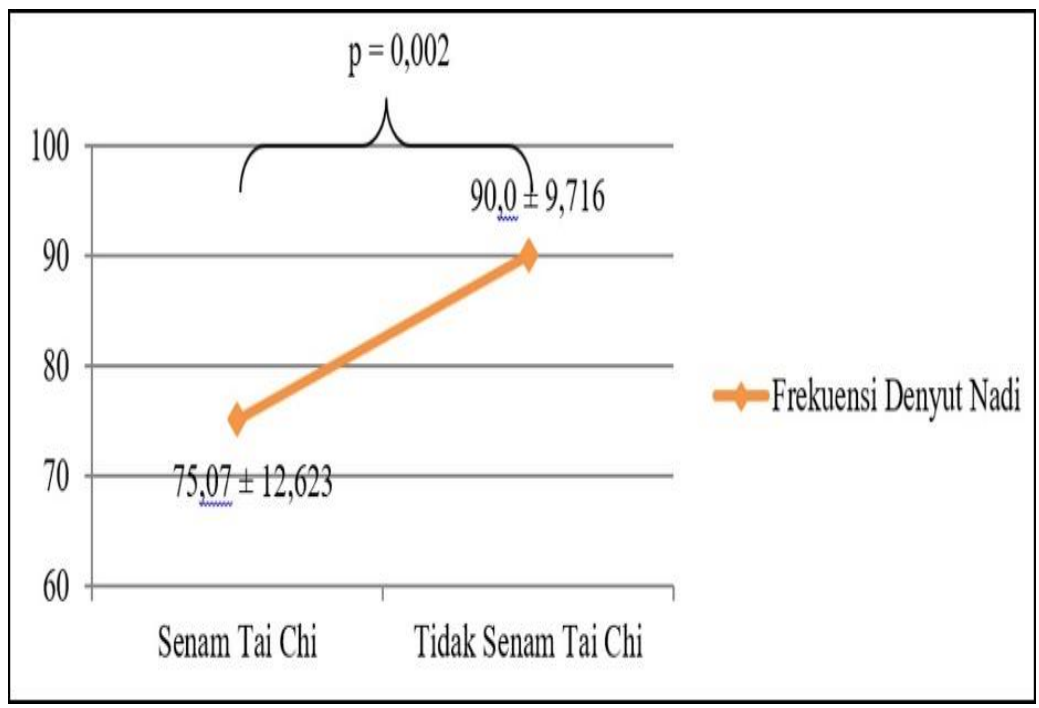

Gambar 6. Perbandingan Frekuensi Denyut Nadi pada Subjek dengan Riwayat Penyakit Kardiovaskular dan Konsumsi Obat Penyakit Kardiovaskular 


\section{Pembahasan}

Peneliti membandingkan tekanan darah sistolik, diastolik, dan frekuensi denyut nadi kedua kelompok dengan kategorisasi masingmasing kelompok untuk meminimalisasi kerancuan hasil penelitian akibat variabilitas karakteristik responden. Beberapa penelitian sudah dilakukan untuk mencari pengaruh dari senam Tai Chi terhadap penurunan tekanan darah.

Pada kelompok yang tidak memiliki riwayat penyakit kardiovaskular, didapatkan hasil bahwa senam Tai Chi memengaruhi tekanan darah sistolik tetapi tidak memengaruhi tekanan diastolik dan frekuensi denyut nadi. Hasil ini sesuai dengan penelitian Sun J dan Buys $\mathrm{N}$ yang membuktikan adanya penurunan tekanan darah sistolik setelah mengikuti senam Tai Chi dalam waktu 12 bulan. ${ }^{19}$ Waktu penelitian berjangka panjang diperlukan untuk mencapai perubahan tekanan diastolik yang signifikan. ${ }^{19}$ Variabilitas denyut jantung yang merupakan perubahan interval waktu antara detak jantung yang berdekatan, muncul dari sistem regulasi tubuh yang saling bergantung dan beroperasi pada skala waktu yang berbeda untuk beradaptasi dan mencapai kinerja yang optimal. $^{20}$ Variabilitas tersebut dipengaruhi oleh aktivitas saraf otonom, tekanan darah, dan sistem pernapasan. ${ }^{20}$ Diperkirakan faktor-faktor tersebut yang memengaruhi tidak ditemukannya hubungan bermakna terhadap frekuensi denyut nadi pada penelitian ini, karena penelitian ini tidak mengukur variabilitas denyut jantung pada kedua kelompok responden.

Pada kelompok yang memiliki riwayat penyakit kardiovaskular, senam Tai Chi memengaruhi tekanan darah sistolik dan frekuensi denyut nadi, tetapi tidak berpengaruh signifikan terhadap tekanan darah diastolik. Studi systematic review senam Tai Chi menurunkan tekanan darah sistolik secara efektif dan menurunkan frekuensi denyut nadi. ${ }^{6}$ Penelitian yang dilakukan Yeh GY dengan durasi pelatihan senam Tai Chi selama 12 minggu hingga 3 tahun, penurunan tekanan darah sistolik dapat mencapai sebesar 7-32 $\mathrm{mmHg}$ dan tekanan diastolik mencapai sebesar 2,4-18 mmHg. ${ }^{6}$ Perbedaan tekanan darah dalam penelitian ini didukung oleh rentang yang tertulis pada penelitian Yeh GY tersebut.

Pada kelompok yang tidak ada riwayat konsumsi obat, terdapat tekanan sistolik dan frekuensi denyut nadi yang lebih tinggi pada subjek yang tidak senam Tai Chi. Meskipun senam Tai Chi tidak memengaruhi tekanan darah diastolik, tetapi didapatkan tekanan darah diastolik yang lebih tinggi pada kelompok yang tidak senam Tai Chi daripada yang senam. Hasil serupa juga diperoleh pada kelompok dengan riwayat penyakit kardiovaskular yang mengonsumsi obat. Sesuai dengan penelitian sebelumnya yang dilakukan Nguyen $\mathrm{MH}$ dan Kruse A yang menyatakan senam Tai Chi memengaruhi tekanan darah sistolik dan frekuensi denyut nadi, tetapi tidak pada tekanan darah diastolik. ${ }^{5}$ Penelitian oleh Supriani A yang bersifat eksperimental menyatakan adanya penurunan tekanan darah sistolik dan diastolik setelah subjek diberi perlakuan senam Tai $C h i .^{21}$ Menurut Sun J dan Buys N, penelitianpenelitian sebelumnya lebih banyak meneliti hubungan senam Tai Chi terhadap tekanan darah dalam kurun waktu beberapa minggu, sedangkan diperlukan waktu setidaknya 12 bulan untuk mengetahui efek jangka panjang dari senam Tai Chi. ${ }^{19}$ Oleh karena itu, dengan keterbatasan waktu, hubungan bermakna pada tekanan darah diastolik dalam penelitian ini tidak ditemukan. Mekanisme pasti dari penurunan tekanan darah oleh senam Tai Chi masih dalam penelitian sampai sekarang.

Dalam suatu penelitian oleh Yeh GY didapatkan penurunan frekuensi denyut nadi didapat dari aktivitas senam Tai Chi. ${ }^{6}$ Senam Tai Chi dapat membantu menurunkan risiko disfungsi endotelial dan aterosklerosis. Dengan secara rutin melakukan senam Tai Chi maka status proliferasi endotelial pembuluh darah meningkat, sehingga dilatasi vaskular pada kulit akan meningkat pula dan mengurangi risiko aterosklerosis. Penelitian oleh Lan C menyatakan kandungan nitric oxide (NO) yang merupakan endothelium-dependent vasodilator dan berperan penting dalam respons vasodilatasi selama olahraga didapatkan lebih tinggi pada kelompok yang melakukan senam Tai Chi. ${ }^{22}$ Senam Tai Chi dapat membantu mengendalikan stres yang merupakan salah satu faktor risiko hipertensi dengan cara latihan pernapasan yang tepat dikombinasikan dengan latihan otot ringan, sehingga membuat seseorang menjadi rileks. Teknik pernapasan dalam dan gerakan yang lambat dapat meningkatkan konsentrasi oksigen di dalam darah, memerlancar aliran darah, dan menurunkan denyut jantung. Gerakan Tai Chi yang meliputi body-mind-soul-breath secara 
teratur terbukti dapat meningkatkan pelepasan noradrenalin melalui urin, menurunkan kadar kortisol, serta menurunkan aktivitas saraf simpatis yang membawa dampak positif pada jantung, berupa denyut jantung yang stabil dan tekanan darah turun menuju normal. ${ }^{21}$

\section{Simpulan}

Dari hasil penelitian hubungan senam Tai Chi dengan tekanan darah dan frekuensi denyut nadi pada usia 45 tahun ke atas yang dilakukan di Kelurahan Duri Kosambi, dapat disimpulkan bahwa:

1. Terdapat hubungan atau perbedaan bermakna antara senam Tai Chi dengan tekanan darah sistolik pada kelompok yang tidak memiliki riwayat penyakit kardiovaskular.

2. Tidak terdapat hubungan antara senam Tai Chi dengan tekanan darah diastolik dan frekuensi denyut nadi pada kelompok yang tidak memiliki riwayat penyakit kardiovaskular, tetapi tekanan darah diastolik dan frekuensi denyut nadi didapatkan lebih tinggi pada kelompok yang tidak senam Tai Chi.

3. Terdapat hubungan antara senam Tai Chi dengan tekanan darah sistolik dan frekuensi denyut nadi pada kelompok yang memiliki riwayat penyakit kardiovaskular.

4. Tidak terdapat hubungan antara senam Tai Chi dengan tekanan darah diastolik pada kelompok yang memiliki riwayat penyakit kardiovaskular, tetapi didapatkan tekanan darah diastolik lebih tinggi pada kelompok yang tidak senam Tai Chi.

\section{Daftar Pustaka}

1. Anggara D, Prayitno N. Faktor-faktor yang berhubungan dengan tekanan darah di Puskesmas Telaga Murni Cikarang Barat tahun 2012. Jurnal Ilmiah Kesehatan. 2013;5(1):20-5.

2. Ambardini RL. Aktivitas fisik lansia. J Chem Inf Model. 2010;53:160.

3. Setiawan GW, Wungouw HISualitas hidup penderita hipertensi. Jurnal eBiomedik. 2013;1(2):760-4.

4. Hikmaharidha I. Pengaruh senam Tai Chi terhadap tekanan darah wanita berusia 50 tahun ke atas. 2011; Available from : http://eprints.undip.ac.id/33315/1/Istifa.

5. Nguyen MH, Kruse A. The effects of Tai
Chi training on physical fitness, perceived health, and blood pressure in elderly Vietnamese. Open Access J Sport Med. 2012;7.

6. Yeh GY, Wang C, Wayne PM, Phillips RS. The effect of Tai Chi exercise on blood pressure: a systematic review. Preventive Cardiology. 2008;11(2):82-9.

7. Sandi IN. Hubungan antara tinggi badan, berat badan, indeks massa tubuh, dan umur terhadap frekuensi denyut nadi istirahat siswa SMKN-5 Denpasar. Sport and Fitness Journal. 2013;1(1):38-44.

8. Moniaga V, Pangemanan DHC. Pengaruh senam bugar lansia terhadap tekanan darah penderita hipertensi di bplu senja cerah paniki bawah. J e-Biomedik. 2013;1(2):785-9.

9. Johansen CD, Olsen RH, Pedersen LR, Kumarathurai P, Mouridsen MR, Binici $\mathrm{Z}$, et al. Resting, night-time, and $24 \mathrm{~h}$ heart rate as markers of cardiovascular risk in middle-aged and elderly men and women with no apparent heart disease. Eur Heart J. 2013;34(23):1732-9.

10. Arif D, Hartinah D. Factors relating to the incident of hypertension in elderly in Klumpit Village Mobile Community Health Center of Gribig Community Health Center, district Kudus. JIKK. 2013;18-34.

11. Thristyaningsih S, Probosuseno AH. Senam bugar lansia berpengaruh terhadap daya tahan jantung, paru, status gizi, dan tekanan darah. Jurnal Gizi Klinik Indonesia. 2011;8(1):14-22.

12. Martin J. Hypertension Guidelines: Revisiting the JNC 7 Recommendations. J Lancaster Gen Hosp. 2008;3(3):91-7.

13. Rahajeng E, Tuminah S. Prevalensi hipertensi dan determinannya di Indonesia. Maj Kedokt Indones. 2009;59(12):580-7.

14. Joint G, Committee N. Analisis JNC 8 : Evidence-based guideline penanganan pasien hipertensi dewasa. CDK..2016;43(1):54-9.

15. Setiawan IWA, Yunani, Kusyati E. Hubungan frekuensi senam lansia terhadap tekanan darah dan nadi pada lansia hipertensi. Dalam: Prosiding Konferensi Nasional II PPNI Jawa Tengah, 2014: 229-36.

16. Pontoh BI, Pangemanan DHC, Mariati NW, Tahun R, Oley AB, Anindita PS. 
Hubungan tingkat kecemasan dengan perubahan denyut nadi pada pasien ekstraksi gigi di Puskesmas Tuminting Manado. Jurnal e-Gigi. 2015;3(1):13-7.

17. Bawiling NS, Adiputra N, Tirtayasa K. Pelatihan senam ayo bergerak, senam bugar Indonesia lebih meningkatkan kebugaran fisik daripada senam ayo bersatu pada wanita anggota klub senam Lala Studio Denpasar. Sport and Fitness Journal. 2014; 2(1):150-61.

18. World Health Organization Expert Consultation. Waist circumference and waist-hip ratio: report of a WHO expert consultation. 2008:8-11.

19. Sun J, Buys N. Community-based mindbody meditative Tai Chi program and its effects on improvement of blood pressure, weight, renal function, serum lipoprotein, and quality of life in Chinese adults with hypertension. Am J Cardiol. 2015;116(7):1076-81.

20. Shaffer F, McCraty R, Zerr CL. A healthy heart is not a metronome: an integrative review of the heart's anatomy and heart rate variability. Front Psychol. 2014;5:119.

21. Supriani A. Pengaruh senam Tai Chi terhadap penurunan tekanan darah pada lansia dengan hipertensi. J Keperawatan Kebidanan - Stikes Dian Husada Mojokerto. 2013;22-30.

22. Lan C, Chen S-Y, Wong M-K, Lai JS. Tai Chi chuan exercise for patients with cardiovascular disease. Evidence-Based Complement Altern Med. 2013;2013:19. 